\title{
THE IMPLICATIONS OF THE ECONOMIC CRISIS FOR POLISH CONSUMER BEHAVIOURS
}

\begin{abstract}
The economic crisis, affecting with varying intensity a host of countries across the world, has not gone unnoticed among Polish consumers and households. The economic slowdown has triggered among consumers and households an array of remedies and adaptations to the changed crisis-time economic realities. Many of the Polish consumers and households, and especially those with lower income, found it imperative to cut down on consumer spending, scale down certain needs and revise their pre-crisis consumption patterns. In Poland the consequences of the recent economic crisis were not so dramatic as in other countries, however the country's economic slowdown had its impact on the standards of living and behaviours of Polish consumers and households, resulting, inter alia, in rationalisation of consumer behaviours and spending. It may be assumed that the latest economic crisis has prodded Polish consumers to reflect on the sense of the pre-crisis fever of creditbased consumption and materialistic approach to life. The basic objective of the paper is to provide an empirical insight and highlight major issues related to the impact of the crisis on Poles' consumer behaviours on the basis of the available research findings, and author's own questionnaire research conducted in 2009 and 2015. An in-depth analysis of the new tendencies in consumer behaviours and consumption patterns of contemporary Poles drawing upon statistical data and latest available research findings may provide useful tips and recommendations for economic policy makers and corporate strategists.

Keywords: economic crisis, consumer behaviour, Poland
\end{abstract}

\section{INTRODUCTION}

The latest global financial and economic crisis, which began in 2007-2008, was sparked off by a crisis on the subprime debt market and in a relatively short period it spilled over to other sectors, morphing into a worldwide recession. Poland was among the affected countries: even if its economic performance proved quite impressive compared to other markets with GDP decreases, the resulting slowdown meant that business had to operate in much deteriorated conditions, while many - especially lower-income - consumers and households faced the necessity of cutting down on consumer spending and revising their previous consumption patterns.

Prior to the crisis, Polish macroeconomic indicators were favourable, with GDP on the rise, unemployment continually going down, inflation at a stable level and consumption growing robustly. Due to the welcome socio-economic changes in the country, many investors perceived Poland as a dynamic economy with potential for growth. Polish consumers and households, able to meet many of their consumer needs and seeing growing affluence, declared increasing satisfaction with the quality of their life.

\footnotetext{
Professor at Warsaw School of Economics, Faculty of Management and Finance, Al. Niepodległości 162, $02-$ 554 Warszawa, Poland; e-mail: bogdan.mroz@sgh.waw.pl, phone/fax: (+48 22) 5649309.
} 
The present article discusses the consequences of the latest economic crisis for Polish consumers and households. It begins with outlining the macroeconomic context of changes in Polish consumer behaviours, which is followed (section 3) with a description of households' problems in the light of research findings and statistical data. Section 4 presents conclusions of the author's empirical study to find out how Polish consumers reacted to crisis-induced economic problems. Selected findings of the author's research into Polish consumers' contribution to the "shadow economy", as a way of cushioning crisisrelated hardship, are highlighted in Section 5, while the final part deals with the weightiest long-term consequences which the crisis has brought on Polish consumers and households. In the concluding part, the reader will find key takeaways from an empirical study by this writer and from literature on crisis-time behaviours by Polish consumers.

\section{THE MACROECONOMIC CONTEXT OF CHANGES IN BEHAVIOURAL PATTERNS OF POLISH CONSUMERS}

Over the past quarter-century, it was many times that Polish households had to adapt to their changing environment and learn how to function in a free market economy. The first stage of Polish transformation was a traumatic experience for many Polish consumers and families, reflecting a drastic decline in real incomes which affected their living standards and consumption. In step with the market economy's consolidation in Poland, affluence levels, living standards and consumption were gradually increasing. The resulting consumerist euphoria and a sense of consumeristic hedonism were then cooled down by the crisis, which came to Poland with a certain time lag. With a set of macroeconomic data which stood out among other countries, Poland has proved fairly resistant to the crisis, which in fact was confined to a delayed slowdown. Still, the country's GDP decelerated, unemployment went up and households saw their conditions deteriorating.

The change from the $7.2 \%$ real GDP growth rate recorded at the peak in 2007 was quite substantial: to $+3.9 \%$ in 2008 and $+2.6 \%$ in $2009^{2}$ - even though the 2009 result meant that Poland was then the only expanding economy in the EU. The next two years witnessed some GDP acceleration (up 3.7\% in 2010, and up 4.8\% in 2011), followed by lower rates in 2012-2013 and a renewed upturn to 3.3\% growth in 2014, as estimated by the Central Statistical Office (Eurostat's figure was up 3.4\%). That came in part as a result of increased consumption ${ }^{3}$.

Thus, following a period of sustained growth, Poland's GDP in 2013 was $14.2 \%$ higher than in 2008 - the year in which most EU countries began to feel the pinch. The runnerup in this classification is Sweden, with $6.7 \%$ growth over the period, while the EU area as a whole reported a combined GDP decline by more than $1 \%{ }^{4}$. In 2015-2016, Polish GDP growth is projected by various institutions - the Polish government, the European Commission, the International Monetary Fund - to run at an average rate of 3.2-3.5\%.

The first symptoms of the economic slowdown began to filter through to the Polish consumers in 2009 , when they still perceived the crisis more like media reports from a distant place than a hard reality. As demonstrated by findings of a CBOS research conducted in early March 2009 on a representative sample of 979 adult Poles, the households

\footnotetext{
${ }^{2}$ Roczne wskaźniki makroekonomiczne. 2015. Warszawa, Główny Urząd Statystyczny.

${ }^{3}$ Analiza sytuacji gospodarczej Polski w 2014 r. 2015. Warszawa, Ministerstwo Gospodarki, March, p. 7.

${ }^{4}$ Polska 2014. Raport o stanie gospodarki. 2014. Warszawa, Ministerstwo Gospodarki, p. 96.
} 
already felt the consequences of the crisis. Some $44 \%$ respondents declared so - an increase of 26 percentage points on November 2008 - whereas $52 \%$ thought otherwise ${ }^{5}$. In 2001 , too, respondents were expressing anxiety about future living standards and family finances. Such concern was declared by $74 \%$ of those happy with their financial status and as many as $91 \%$ of those unhappy. Respondents below 35 years of age, inhabitants of large cities (with above 100,000 population) and university/college graduates were slightly more likely to state that they were not afraid of a crisis threat. Asked about which hardships they associate with the crisis, respondents most frequently pointed to being forced to cut spending on food (48\%), being affected by structural redundancies at the workplace (48\%) and having one's pension payments delayed (43\%). For one in five (22\%) the crisis would mean having to cut down electricity consumption, and for $15 \%$ it would mean a loss of savings due to bank bankruptcy ${ }^{6}$.

Asked in a 2014 Eurobarometer survey about the most series problems facing the country, respondents most frequently indicated unemployment $(60 \%)$, the economic situation $(22 \%)$, and rising prices/inflation $(19 \%)$. When replying to questions about their personal perception, they pointed to rising prices/inflation (30\%), unemployment $(27 \%)$, the financial condition of their household (17\%) and health and security (16\%), while the country's overall economic situation (12\%) and pensions (16\%) stayed further down the list. Well, people indeed seem to be "looking for number one" - and Poles, accordingly, take greater interest in the condition of their household budgets than of the country's economy ${ }^{7}$.

\section{PROBLEMS FACED BY POLISH HOUSEHOLDS IN MEETING THEIR NEEDS IN TIME OF CRISIS}

Seeking to adjust to their changing environment, households tend to alter their consumer behaviours which are strongly determined by their financial status, and particularly the income level. Some Polish households actually have problems with satisfying their needs, including basic needs such as food.

One manifestation of adjustment to the new, worsened conditions is when more economical ways of meeting one's needs are embraced - whether in terms of shopping or household maintenance.

In a survey taken in April-May 2009 by the Centre for Consumer Behaviour Research at the Warsaw School of Economics, respondents admitted to cutting down on consumption, giving up some consumer purchases and switching to cheaper substitutes. They also opted to limit using paid-up services, and either switch to DIY or give up a service entire1y. The biggest reductions were in spending on out-of-home entertainment $(62.1 \%$ respondents), electronic gadgets $(62.1 \%)$ and electricity, gas and water bills $(61.4 \%)^{8}$. Problems with meeting their needs were also signalled by respondents in a comprehensive

\footnotetext{
${ }^{5}$ Odczuwane i przewidywane konsekwencje kryzysu. 2009. Komunikat CBOS, BS/51/2009, Warszawa, March.

${ }^{6}$ Czy Polacy boją się kryzysu. 2012. Komunikat CBOS, BS/2/2012, Warszawa, January.

${ }^{7}$ Living conditions in the European Union. 2014. Eurobarometer Standard 81, report, Spring 2014 - TNS opinion \& social, Brussels, European Commission, pp. 5-24.

${ }^{8}$ Reakcje polskiego konsumenta na kryzys gospodarczy, ed. by Teresa Słaby. 2009. Warszawa, Szkoła Główna Handlowa, pp. 53-55.
} 
national study of all major aspects of the life of Poles, known as "Societal Diagnosis"9. Contacted in early 2013, households described such problems as minor (36\% respondents), regular (20\%) and considerable (more than $17 \%$ ).

The past four years saw an increase in the percentage of households who declared leading a very frugal life in order to save for basic necessities (up 5 percentage points, from $17.2 \%$ to $22.6 \%$ ). At the other end of the spectrum, there were decreases in the respective percentages of households who declared following a frugal way of life and, as a result, keeping their heads above water (down by more than 2 percentage points, from $39.2 \%$ to $37.1 \%$ ) and not saving but still having enough to meet all their needs (down by nearly 2 percentage points, from $10.1 \%$ to $8.2 \%$ ). Problems appear not only with meeting needs related to food, but also non-food articles, including consumer durables. While durables' penetration of households in Poland has been continually improving, there are still households not capable financially to buy such items. In early 2013, financial constraints were a factor behind not purchasing an apartment/house (as declared by $60 \%$ of the households not in possession of these items), an automatic washing machines (some $59 \%$ ) and an LCD/plasma TV set (nearly 59\%).

According to a CBOS research, the percentage of households encountering financial constraints in meeting their needs has dropped in recent years. In particular, households felt short of money for the purpose of rest and recreation (holidays, children's summer/winter camps). purchase of home furnishings, culture and medical treatment. Lower percentages were reported in respect of financial constraints on clothing/footwear purchases, household bills, food purchases, education and personal hygiene (cf. Table 1).

Table 1. Households' financial constraints on purchases of selected goods/services in 2010, 2011 and $2014^{*}$

\begin{tabular}{|l|c|c|c|}
\hline \multirow{2}{*}{$\begin{array}{l}\text { Spending category/ Consumer goods or } \\
\text { services not purchased due to shortage of } \\
\text { funds: }\end{array}$} & \multicolumn{3}{|c|}{ \% of respondents } \\
\cline { 2 - 4 } $\begin{array}{l}\text { Recreation (holidaying, children's sum- } \\
\text { mer/winter camps) }\end{array}$ & 41 & 45 & 41 \\
\hline Home furnishings & & & \\
\hline $\begin{array}{l}\text { Culture (books, papers, theatre, concerts, } \\
\text { etc.) }\end{array}$ & 2010 & 42 & 38 \\
\hline Medical treatment & 26 & 28 & 25 \\
\hline Clothing and footwear & 25 & 27 & 21 \\
\hline Household bills (utilities, rent, etc.) & 21 & 23 & 20 \\
\hline Food & 18 & 19 & 18 \\
\hline Education & 12 & 19 & 16 \\
\hline Cleaning agents, personal hygiene & 13 & 14 & 11 \\
\hline
\end{tabular}

* Last 12 months preceding the study

Source: Jak nam się żyje? Materialny wymiar życia rodzin. 2014. Komunikat CBOS nr 44/2014, Warszawa, April, http://cbos.pl/SPISKOM.POL/2014/K_044_14.PDF (accessed: 16 January 2016).

\footnotetext{
${ }^{9}$ Diagnoza Społeczna 2013. Warunki i jakość życia gospodarstw domowych. Polaków - Raport. [Special issue]. 2013. DOI: 10.5709/ce.1897-9254.99, available at: http://www.ce.vizja.pl/en/issues/volume/7/issue/3.1, accessed 20 January 2016.
} 
Problems with current expenditure were felt primarily by the households describing their financial situation as bad (19\% had not enough even for basic necessities, and 62\% had to economise intensely on a daily basis). Among those who declared being in an average financial condition, $74 \%$ said they had enough for current spending but had to save for higher value purchases, while one in four $(23 \%)$ had to save to allow even everyday shopping. As regards the respondents perceiving the financial situation of their households as good, half of them $(51 \%)$ believe economising is not needed in respect of current spending but is required in order to enable higher value purchases. Two-fifths of the respondents $(40 \%)$ declare living without saving ${ }^{10}$.

Crisis-time saving is not only a Polish phenomenon, and saving methods are similar in different countries. As demonstrated by a research carried out by the GfK institute, 39\% of Poles declare cutting down on their food spending, and the same is declared by $38.6 \%$ of French people, $35.7 \%$ of Britons and $42.7 \%$ of Italians. Spending was down also in restaurants and pubs, where in 2011 Western European consumers left 13\% less money than in 2007. Culture is another affected sector, with spending reduced by $41 \%$ of the French, $33.6 \%$ of Britons and $26 \%$ of the Dutch ${ }^{11}$.

In a 2013 survey, the Polish polling institute CBOS enquired about purchases during the preceding 12 months of various items, including cars, furniture and home furnishings, computers and other electronic equipment. It turned out that the purchase of all these categories was declared by fewer respondents in April 2013, as compared to July 2012. The proportion of those declaring purchase of furniture and/or household appliances was down 6 percentage points; the corresponding change for purchase of computers was down 5 points and for other electronic equipment it was as steep as down 9 percentage points (to a $26 \%$ proportion overall, including $15 \%$ for TV sets and $24 \%$ for digital cameras). Asked about plans for the coming 12 months, one in ten declared the intention to purchase furniture and home appliances $(11 \%)$, one in thirteen a car, the same proportion a piece of electronic equipment (e.g. a TV set, a digital camera), $8 \%$ an iPod, and $5 \%$ a computer ${ }^{12}$.

\section{REACTIONS OF THE POLISH CONSUMERS TO THE ECONOMIC PROB- LEMS - FINDINGS OF EMPPIRICAL RESEARCH BY THE AUTHOR}

Seeking to establish how the crisis impacts Polish consumers and households, the Centre for Consumer Behaviour Research of the Warsaw School of Economics launched a twostage project, conducted in 2009 and 2015 among respondents representing urban households in seven selected towns of Mazowieckie Voivodship (Ciechanów, Ostrołęka, Płock, Radom, Siedlce, Sochaczew, Żyrardów). Judgmental (purposive) sampling and questionnaire research were used in the project which involved the same sample size of 365 in both years, and which asked respondents an identical set of questions on how far their needs have been satisfied. To ensure the same sample structure in 2009 and 2015, the weighing procedures were followed which are often used in research based on quota sampling and purposive sampling. With research replication, a comparative perspective was

\footnotetext{
${ }^{10}$ Ibidem.

${ }^{11}$ Wydatki Polaków: wprowadzamy w domu politykę oszczędności, http://forsal.pl/artykuly/689874,wydatki_polakow_wprowadzamy_w_domach_polityke_oszczednosci.html, accessed: 16 January 2016.

12 Zmiany w postrzeganiu kryzysu i zachowaniach ekonomicznych Polaków. 2013. Komunikat CBOS, BS/152/2013, Warszawa, October.
} 
sought to juxtapose the findings of 2009 and 2015, and identify behavioural changes among Polish consumers and households over six years ${ }^{13}$.

Ten attitudes towards the crisis were researched, broadly divided into three groups:

- protective (economising on "anything you can"; bringing down consumption to absolute necessity, buying in advance "while I still can afford");

- problem-tackling (seeking help from family, friends/acquaintances or NOGs; migrating to work abroad, taking up work in the informal sector of the economy);

- $\quad$ alternative (taking jobs with lower skill requirements, accepting lower pay).

Table 2. Reactions of Mazowieckie Voivodship respondents to economic problems (\%)*

\begin{tabular}{|l|c|c|}
\hline \multicolumn{1}{|c|}{ Attitude } & 2009 & 2015 \\
\hline economising on "anything you can"; & 40.9 & 59.0 \\
\hline bringing consumption down to necessity & 30.8 & 64.0 \\
\hline buying in advance "while I still can afford"); & 16.5 & 31.0 \\
\hline seeking help from family & 11.3 & 49.0 \\
\hline taking up work in shadow economy & 11.0 & 46.0 \\
\hline seeking help from acquaintances & 9.9 & 43.0 \\
\hline seeking help from NGOs & 9.1 & 44.0 \\
\hline migrating to work abroad & 8.0 & 52.0 \\
\hline taking jobs with lower skill/education requirements & 7.7 & 56.0 \\
\hline taking lower-paid jobs & 6.0 & 43.0 \\
\hline
\end{tabular}

* Respondents could indicate more than one reply.

Source: Author's compilation based on findings of empirical research in 2009 and 2015.

In 2009, soon after early signs of the crisis emerged in the Polish economy - carrying, in particular, the threat of job losses - two protective attitudes proved dominant: economising on "anything you can", (indicated by $40.9 \%$ respondents) and bringing consumption down to necessity $(30.8 \%)$. These attitudes, and especially the latter, were found to be much more frequent in the 2015 survey, which may point to either harder economic problems, as compared with six years previously, or a greater propensity to save and control everyday spending. The second explanation seems more convincing, given that 2015 saw a much lower percentage of those fearing a job loss $(47 \%)$ while at the same time the proportion increased of those respondents who declared bringing consumption down to necessity. Rationalisation of consumer behaviour thus proved to be a side-effect of the crisis. The 2015 numbers reveal lower spending on clothing/footwear by $73 \%$ respondents, on energy by $80 \%$ respondents, on out-of-home entertainment by $80 \%$, on gadgets by $77 \%$, on eating out by $75 \%$, and on food by $67 \%{ }^{14}$.

In $2009,77.5 \%$ of the respondents actively responded to expected economic problems, and the proportion seen in 2015 was similar (76.0\%). There was an unchanged percentage in both years (some $31 \%$ ) of those seeking comfort in religious practice, and a small drop in the share of those expecting government help and assistance in improving the labour

\footnotetext{
${ }^{13}$ Zmiany zachowań polskich gospodarstw domowych pod wpływem kryzysu, ed. by Bogdan Mróz. 2015. Warszawa, Szkoła Główna Handlowa.

14 Anna Dąbrowska, Mirosława Janoś-Kresło, Bogdan Mróz, Teresa Słaby. 2015. Zmiany zachowań polskich gospodarstw domowych pod wpływem kryzysu - II etap. Gospodarstwa miejskie - badania empiryczne, Warszawa, Szkoła Główna Handlowa, October.
} 
market situation. Significantly, the percentage increased of those dispelling/ignoring fears of the future - from $6.3 \%$ in 2009 to $11 \%$ in 2015 - which may reflect a 2015 increase in social transfers and, possibly, a weakening of motivation to work and actively seek improvement in the economic situation of consumers and households ${ }^{15}$.

In both surveys, answers were sought to the question of how a worsening of consumers' and households' financial situation influenced their use of paid services - remembering about substitutive relationship between paid services and household members' own provision (some activities, such as house/apartment cleaning can be outsourced on a commercial basis).

The comparison of 2009 and 2015 findings of the empirical research confirms the conjecture that households' worsened financial situation leads to a reduction or abandonment of paid services. The intensity of this reduction/abandonment is diversified in accordance with respondents' socio-economic characteristics, but it is noteworthy that the relevant percentages increased perceptibly in 2015. The strongest impact of aggravated economic situation on service reduction/abandonment was seen in respect of services which meet less urgent needs, further down in hierarchy (e.g., tourism, culture) and services which can be replaced with work performed by household members themselves (e.g., renovation/construction, cooking). The biggest differences between replies given in 2009 and 2015 were seen in respect of caregiving, renovation/construction, insurance and foodserving - cf. Table $3^{16}$.

Table 3. Categories where a worsened financial situation has influenced or will influence limitation/abandonment of using a paid service

\begin{tabular}{|l|c|c|}
\hline \multicolumn{1}{|c|}{ Service category } & $\mathbf{2 0 0 9}$ & $\mathbf{2 0 1 5}$ \\
\hline Tourism & 56 & 79 \\
\hline Culture and culture -related & 46 & 75 \\
\hline Food-serving & 43 & 75 \\
\hline Repair/construction & 45 & 82 \\
\hline Telecommunications & 35 & 59 \\
\hline Banking & 31 & 58 \\
\hline Insurance & 26 & 60 \\
\hline Education & 25 & 52 \\
\hline Caregiving & 21 & 60 \\
\hline Medical & 20 & 49 \\
\hline
\end{tabular}

Source: Author's compilation based on findings of 2009 and 2015 surveys.

\footnotetext{
${ }^{15}$ Zmiany zachowań polskich gospodarstw domowych pod wpływem kryzysu, ed. by Bogdan Mróz, op. cit.

${ }^{16}$ Anna Dąbrowska, Mirosława Janoś-Kresło M., Bogdan Mróz, Teresa Słaby. 2015. Zmiany zachowań polskich gospodarstw domowych pod wpływem kryzysu - II etap. Gospodarstwa miejskie - badania empiryczne, op. cit.
} 


\section{PARTICIPATION IN SHADOW ECONOMY AS A WAY TO LIMIT CRISIS CONSEQUENCES FOR POLISH HOUSEHOLDS}

In response to the economic crisis, a tough labour market situation and shrinking wage earning opportunities in the official sector, consumers and households resort to a variety of adaptation strategies. These may include the following:

- households forgo meeting some needs and bring down consumption, adjusting it to their lower income earning potential;

- consumers seek to keep at any price the pre-crisis living standards and consumption levels, looking for new income earning opportunities (including in the shadow economy). The ratchet effect, widely covered in literature on consumer behaviour, is at work here.

One behavioural variant of coping with the crisis, in conditions of official sector redundancies, is to delve into the shadow economy which then acts as a buffer against shocks in the official sector, producing income earning opportunities for many households. This option, as a means of cushioning the consequences of economic slowdown and preserving the living standards and consumption levels, was indicated by quite many respondents in the 2015 survey in seven Mazowieckie Voivodship towns (Ciechanów, Ostrołęka, Płock, Radom, Siedlce, Sochaczew, Żyrardów) (cf. Table 4).

Table 4. Seeking jobs in the informal sector as a means of coping with the crisis in 2009 and 2015

\begin{tabular}{|l|c|c|}
\hline \multirow{2}{*}{ Total and in breakdown by age } & \multicolumn{2}{|c|}{ \% of respondent indications } \\
\cline { 2 - 3 } bracket, education and net income & 2009 & 2015 \\
\hline Total & 11 & 44 \\
\hline Age group & 13 & 38 \\
- 25-34 & 10 & 46 \\
- 35-44 & 15 & 43 \\
- 45-54 & 7 & 50 \\
- 55-64 & 12 & 40 \\
\hline Education & 11 & 53 \\
- primary/vocational & 12 & 40 \\
- secondary & & \\
- higher & 15 & 54 \\
\hline Net income of household & 10 & 35 \\
- up to 2000 zł (€ 450) & 14 & 41 \\
- 2001-3000 zł (€451-680) & 6 & 43 \\
- 3001-4000 zł (€681-910) & 17 & 44 \\
- 4001-5000 zł (€911- 1135) & 8 & 60 \\
- above 5000 zł (€1135) & & \\
- reply refused & & \\
\hline
\end{tabular}

Source: Author's compilation based on findings of empirical research.

The survey demonstrates that taking jobs in the informal sector is seen by respondents as an important means of replenishing the family purse. In $2015,44 \%$ respondents admitted to looking for shadow economy jobs in an effort to mitigate the consequences of the crisis (against just 11\% in 2009). A comparison of 2009 and 2015 findings reveals an enormous increase in informal sector engagement in all breakdowns (by age, education, 
income, etc.) - cf. Table 4. The percentages of items bought from the informal sector rose in all product/service categories over 2009-2015 $5^{17}$. The most spectacular change was in alcoholic beverages, where this proportion increased nearly six times, followed by computer equipment/accessories (nearly threefold increase in the percentage in question) and cosmetics (percentage almost doubled). In services, the top table includes house/apartment cleaning and window washing (nearly threefold growth in the proportion of such services purchased from the shadow economy), private teaching (where the percentage more than doubled), and repair of home appliances and radio/TV equipment (more than doubling) cf. Table 5 .

Table 5. Goods and services purchased from the informal sector in Mazowieckie Voivodship towns under study in 2009 and 2015

\begin{tabular}{|l|c|c|}
\hline \multirow{2}{*}{ Product/service } & \multicolumn{2}{|c|}{ \% of respondent indications } \\
\cline { 2 - 3 } & 2009 & 2015 \\
\hline Food & 40 & 71 \\
\hline Clothing & 64 & 80 \\
\hline Footwear & 53 & 72 \\
\hline Home appliances & 41 & 46 \\
\hline Alcoholic beverages & 6 & 34 \\
\hline Cigarettes & 31 & 52 \\
\hline Cosmetics & 34 & 66 \\
\hline $\begin{array}{l}\text { Computer equip- } \\
\text { ment/accessories }\end{array}$ & 14 & 46 \\
\hline Computer software & 20 & 36 \\
\hline CD & 17 & 36 \\
\hline Repair/construction & 49 & 49 \\
\hline Caregiving & 14 & 34 \\
\hline $\begin{array}{l}\text { House/apartment cleaning, } \\
\text { window washing }\end{array}$ & 11 & 32 \\
\hline Private teaching & 17 & 39 \\
\hline Car repair & 38 & 51 \\
\hline $\begin{array}{l}\text { repair of home appliances and } \\
\text { radio/TV equipment }\end{array}$ & 22 & 54 \\
\hline
\end{tabular}

* Replies do not add to 100 because respondents could indicate more than one product/service. Source: Author's compilation based on findings of empirical research.

Such eye-catching increase in the proportion of respondents using informal-sector products and services brings up a question about its underlying causes. While a precise answer is hard to obtain, two factors seem to be coming to the fore. The respondents in the Mazowieckie Voivodship towns under review must have felt the pinch of the economic crisis, and their dire financial condition forced them to increasingly buy goods and ser-

\footnotetext{
${ }^{17}$ Bogdan Mróz, Rola szarej strefy w zaspokajaniu potrzeb polskich konsumentów w warunkach kryzysu gospodarczego, in: Reakcje polskiego konsumenta na kryzys gospodarczy. 2009. ed. by Teresa Słaby, Warszawa, Szkoła Główna Handlowa; A. Dąbrowska, Mirosława Janoś-Kresło, Bogdan Mróz, Teresa Słaby. 2015. Zmiany zachowań polskich gospodarstw domowych pod wpływem kryzysu - II etap. Gospodarstwa miejskie - badania empiryczne, op. cit.
} 
vices from suppliers in the unofficial sector. But a poor financial condition alone does not explain the scale of this increase. A likely explanation is that in 2015 respondents were more open and prepared to admit buying from the shadow economy, not seeing anything wrong in that. It may be that consumer attitudes and mentality changed over the period towards being more permissive: being a customer of the informal sector is now perceived differently, no longer attracting sharp moral criticism and no longer carrying a stigma.

Table 6. Purchases of goods and services from the informal sector as reaction to economic crisis

(Faced with an economic crisis, do you or your household members buy goods and services without requesting a bill/invoice [i.e., in the shadow economy]?)

\begin{tabular}{|c|c|c|}
\hline \multirow{2}{*}{$\begin{array}{l}\text { Total and in breakdown by } \\
\text { gender, age bracket, education } \\
\text { and town }\end{array}$} & \multicolumn{2}{|c|}{$\%$ of respondent indications } \\
\hline & 2009 & 2015 \\
\hline Total & 18 & 38 \\
\hline $\begin{array}{l}\text { Age } \\
\text { - women } \\
\text { - men }\end{array}$ & $\begin{array}{l}14 \\
21\end{array}$ & $\begin{array}{l}34 \\
42\end{array}$ \\
\hline $\begin{array}{l}\frac{\text { Age }}{-25-34} \\
-35-44 \\
-45-54 \\
-55-64\end{array}$ & $\begin{array}{c}22 \\
17 \\
23 \\
9\end{array}$ & $\begin{array}{l}35 \\
30 \\
41 \\
47\end{array}$ \\
\hline $\begin{array}{l}\text { Education } \\
\text { - primary/vocational } \\
\text { - secondary } \\
\text { - higher }\end{array}$ & $\begin{array}{l}20 \\
14 \\
20\end{array}$ & $\begin{array}{l}58 \\
42 \\
30\end{array}$ \\
\hline $\begin{array}{l}\text { Town } \\
\text { - Ciechanów } \\
\text { - Ostrołęka } \\
\text { - Płock } \\
\text { - Radom } \\
\text { - Siedlce } \\
\text { - Sochaczew } \\
\text { - Żyrardów } \\
\end{array}$ & $\begin{array}{c}15 \\
9 \\
16 \\
15 \\
33 \\
17 \\
17\end{array}$ & $\begin{array}{l}54 \\
45 \\
25 \\
32 \\
36 \\
20 \\
56\end{array}$ \\
\hline $\begin{array}{l}\text { Net household income } \\
\text { - up to } 2000 \mathrm{zł}(€ 450) \\
\text { - 2001-3000 zł (€451-680) } \\
\text { - 3001-4000 zł (€681-910) } \\
\text { - 4001-5000 zł (€911-1135) } \\
\text { - above 5000 zł (€1135) } \\
\text { - reply refused }\end{array}$ & $\begin{array}{l}21 \\
19 \\
21 \\
24 \\
16 \\
10\end{array}$ & $\begin{array}{l}65 \\
30 \\
29 \\
36 \\
28 \\
56\end{array}$ \\
\hline
\end{tabular}

Source: Author's compilation based on findings of empirical research.

In their efforts to brave the economic crisis, consumers and households - in addition to looking for additional employment outside the official sector - also seek to rationalise their consumer spending, and one way of achieving this is through buying some goods 
and services from the shadow economy. Such acquisitions are often of inferior quality, coming with no backup servicing but their costs are perceptibly lower, thus pulling consumers and households into the embrace of the informal sector.

This was confirmed by findings of the author's own research, demonstrating that entrenchment-induced purchases from the informal economy were declared by a much higher proportion of the respondents in 2015 (38\%) than in $2009(18 \%)$. Buying on the unofficial market was more frequent among men (42\%) than women (34\%) and among elderly people (47\% of the respondents in the 55-64 age bracket - cf. Table 6). Seen from another angle, the heaviest buyers in the shadow economy are those with primary/vocational education (58\% respondents in that group).

In by-income breakdown, the penetration of shadow economy purchases is strongest among households with the lowest net incomes, below 2,000 zloty (€450) per household (64\% respondents representing households in this income bracket). Among the researched towns of Mazowieckie Voivodship, the highest percentage of respondents who in 2015 purchased from the second economy with a view to economising was in Żyrardów (56\%) and Ciechanów (54\%), and the lowest in Płock - 25\% and Sochaczew - 20\% ${ }^{18}$.

\section{WHAT THE CRISIS TAUGHT POLISH CONSUMERS}

In the past quarter-century, and especially in the early, traumatic years of transition, Polish consumers often found themselves compelled to adjust to the changing economic conditions. Following the switch from a centrally planned economy towards a free market system, real incomes took a nosedive and people had to reinvent themselves in the new economic realities.

With the "shock therapy" receding into the past, living standards and consumption levels gradually began to recover and Poles grew accustomed to hard economic constraints when planning their consumer spending. In step with these processes, a modern consumer society could be seen emerging in Poland, complete with a fascination for the world of shiny merchandise and shopping malls. With the economy picking up speed, expansive consumerism and materialistic values found a fertile ground among the growing numbers of Polish consumers.

The crisis of the 21st century's first decade came as a cold shower for the consumer spree which was largely credit-financed (especially with respect to real estate and certain durables). Polish consumers and households were thus required to sit a test - so to speak of maturity in conditions of a modern capitalist economy, with its natural cycles of expansion and contraction. It is fair to say that they passed this test, while enriching themselves with new insights and experiences.

After a period of uncritical enthusiasm over the new system (a syndrome of "Alice in capitalist wonderland"), Polish consumers have grown more mature, more aware and better aligned with the realities of a free market economy ${ }^{19}$. The recent economic crisis thus had a positive side to it, by toughening Polish consumer and households, and injecting in them a resistance to the vicissitudes of modern-day cyclical fluctuations. Adjustment to the crisis-induced changes in economic conditions was more mature than in the

\footnotetext{
${ }^{18}$ Anna Dąbrowska, Mirosława Janoś-Kresło, Bogdan Mróz, Teresa Słaby. 2015. Zmiany zachowań polskich gospodarstw domowych pod wpływem kryzysu - II etap. Gospodarstwa miejskie - badania empiryczne, op. cit.

${ }^{19}$ Bogdan Mróz, Konsument w globalnej gospodarce, Trzy perspektywy. 2013. Warszawa, Oficyna Wydawnicza, Szkoła Główna Handlowa.
} 
early stages of the country's systemic transformation in the early 1990s, when a trauma of crashing into market economy realities was followed by a swift increase in consumption.

Still, the Polish consumers and households have yet to match their counterparts in the most advanced capitalist countries when it comes to reading the macroeconomic signals that precede a downturn and quickly adjusting to the changing economic conditions. This is understandable, remembering that the building of economic awareness and smart consumer education require a lot of time to complete and have to be backed by "empirical tests" of how economic perturbations influence the everyday life of consumers and households, bringing new experiences in the process.

It is hard to establish unequivocally how much the change in Poles' living conditions induced by economic slowdown has influenced subjective assessments of the quality of peoples' lives. It can only be surmised that where consumption of certain goods and services caved in, this found reflection in lower subjective assessments of the quality of life in those households. In other households, the assessment of how economic slowdown has impacted the quality of life was strongly diversified, in accordance with the extent of deprivation of needs, levels of aspiration, membership in certain social/occupational groups, etc.

Polish households took an attempt to limit the consequences of economic slowdown by taking various kinds of remedial action and adaptation to the changed crisis-time economic conditions. The adjustment effort was focused on seeking to keep the pre-crisis living standards and consumption levels, giving up on the meeting of some needs, revising consumption priorities of household members, and cutting down on some consumer expenditures.

Poland is a country "working its way up", where consumption and quality of life still lag far behind the most advanced capitalist nations. Some consumers, seeking to catch up in a civilisation race and yearning for Western affluence, have turned to credit as a means of fulfilling their rampant consumer aspirations and financing purchases of some consumer goods (especially homes/apartments, cars, furniture, consumer electronics, home appliances, etc.). This led to an increase in households debt and problems with repayment. It would certainly be a welcome development if both lenders and borrowers in Poland took to heart the tenets of responsible lending and borrowing. Large-scale public education campaigns would be welcome here. Consumers should realise that the consequences of their decisions about going into debt will have to be borne for years to come, and that the price of chasing consumer goods and living beyond one's means may prove to be excessive. It is to be hoped that this will be among the key lessons drawn from the latest economic crisis by Polish consumers and households.

\section{CONCLUDING REMARKS}

While the consequences of the latest crisis for the Polish economy have been less painful than in other countries and coming with some delay, the economic slowdown did make some impact on consumers and households. Slower growth of the official sector had the effect of curtailing income-earning opportunities and causing problems with the balancing of many households' budgets.

The present article highlights selected aspects of Polish households' efforts to adjust to the consequences of the economic crisis. The analysis of changes in the level and structure of consumption spending leads one to conclude that Polish households have demonstrated 
an ability to adjust to the changing economic realities, as reflected in their planning family budgets more rigorously, restricting and/or rationalising some consumer spending items, giving up on the satisfaction of some higher-order needs, controlling expenditure on electricity/gas/water, looking for new sources of income, working in the shadow economy, etc.

One could therefore venture the opinion that, to a certain extent, the latest economic crisis played an educational role, by giving Polish consumers and households a lesson in how to function in a free-market capitalist economy where cyclical ups and downs are a matter of course. Importantly, it has been a key takeaway from the crisis for consumers that economic growth has its limits, and that the path of rampant consumerism, debt and living beyond one's means may lead many of them into a deadly trap.

\section{REFERENCES}

[1] Analiza sytuacji gospodarczej Polski w 2014 r. 2015. Warszawa, Ministerstwo Gospodarki, March.

[2] Czy Polacy boją się kryzysu. 2012. Komunikat CBOS, BS/2/2012, Warszawa, January.

[3] Dąbrowska Anna, Janoś-Kresło Mirosława, Mróz Bogdan, Słaby Teresa. 2015. Zmiany zachowań polskich gospodarstw domowych pod wpływem kryzysu - II etap. Gospodarstwa miejskie - badania empiryczne, Warszawa, Szkoła Główna Handlowa, October.

[4] Diagnoza Społeczna 2013. Warunki i jakość życia gospodarstw domowych. Polaków Raport. [Special issue]. DOI: 10.5709/ce.1897-9254.99, available at:

http://www.ce.vizja.pl/en/issues/volume/7/issue/3.1, accessed 20 January 2016.

[5] Goyal Sandeep, Sergi Bruno S., Jaiswal Mahadeo P. 2016. Understanding the challenges and strategic actions of social entrepreneurship at the base of the pyramid. "Management Decision", Vol. 54, No. 2, pp. 418-440.

[6] Jak nam się żyje? Materialny wymiar życia rodzin. 2014. Komunikat CBOS nr 44/2014, Warszawa, April.

[7] Kryzys czy porządki? Rośnie handel rzeczami używanymi. 2014. Available at: http://www.wprost.pl/ar/396943/Kryzys-czy-porzadki-Rosnie-handel-rzeczami-uzywanymi/\#an2143388771, accessed 18 December 2014.

[8] Living conditions in the European Union. 2014. Eurobarometer Standard 81, report, Spring 2014 - TNS opinion \& social, Brussels, European Commission.

[9] Mróz Bogdan. 2013. Konsument w globalnej gospodarce, Trzy perspektywy, Warszawa, Oficyna Wydawnicza, Szkoła Główna Handlowa.

[10] Mróz Bogdan. 2009. Rola szarej strefy w zaspokajaniu potrzeb polskich konsumentów w warunkach kryzysu gospodarczego, in: Reakcje polskiego konsumenta na kryzys gospodarczy, ed. by Teresa Słaby, Warszawa, Szkoła Główna Handlowa.

[11] Mróz Bogdan (ed.). 2015. Zmiany zachowań polskich gospodarstw domowych pod wpływem kryzysu, Warszawa, Szkoła Główna Handlowa.

[12] Odczuwane i przewidywane konsekwencje kryzysu. 2009. Komunikat CBOS, BS/51/2009, Warszawa, March.

[13] Panek Tomasz, Białowolski Piotr, Kotowska Irena, Czapiński Janusz. 2013. Warunki życia. Zasobność materialna, in: Diagnoza Społeczna 2013. Warunki i jakość życia gospodarstw domowych. Polaków - Raport. [Special issue]. DOI: 10.5709/ce.1897-9254.99, available at: http://www.ce.vizja.pl/en/issues/volume/7/issue/3.1, accessed 20 January 2016.

[14] Roczne wskaźniki makroekonomiczne. 2015. Warszawa, Główny Urząd Statystyczny.

[15] Słaby Teresa (ed.). 2009. Reakcje polskiego konsumenta na kryzys gospodarczy, Warszawa, Szkoła Główna Handlowa.

[16] Wydatki Polaków: wprowadzamy w domu politykę oszczędności. 2016. http://forsal.pl/artykuly/689874,wydatki_polakow_wprowadzamy_w_domach_polityke_oszcz ednosci.html, accessed: 16 January 2016. 
[17] Zmiany w postrzeganiu kryzysu i zachowaniach ekonomicznych Polaków. 2013. Komunikat CBOS, BS/152/2013, Warszawa, October.

\section{WPLYW KRYZYSU GOSPODARCZEGO NA ZACHOWANIA KONSUMPCYJNE POLSKICH KONSUMENTÓW}

Kryzys gospodarczy, który z różną intensywnością odczuło wiele krajów na świecie nie pozostał bez wpływu na zachowania polskich konsumentów i gospodarstw domowych. Spowolnienie gospodarcze uruchomiło całą serię reakcji dostosowawczych i strategii adaptacyjnych do zmienionych kryzysowych realiów gospodarowania. Wiele gospodarstw domowych, zwłaszcza dysponujących niższymi dochodami, zmuszonych było ograniczyć wydatki konsumpcyjne i zaspokojenie niektórych potrzeb oraz zrewidować przedkryzysowe wzorce konsumpcji. W Polsce konsekwencje ostatniego kryzysu gospodarczego nie były tak dramatyczne, jak w innych krajach, jednak spowolnienie gospodarcze wpłynęło na standard życia i zachowania polskich konsumentów oraz gospodarstw domowych, skutkując m.in. racjonalizacją ich zachowań i wydatków konsumpcyjnych. Można również sądzić, że ostatni kryzys gospodarczy skłonił polskich konsumentów do refleksji nad przedkryzysową gorączką konsumpcji opartej na zaciąganiu kredytów, rewizji systemów wartości, a także do porzucenia, lub przynajmniej ograniczenia, materialistycznego nastawienia do życia. Podstawowym celem artykułu jest naświetlenie najważniejszych zagadnień związanych z wpływem kryzysu na zachowania konsumpcyjne polskich konsumentów na podstawie dostępnych wyników różnych badań empirycznych oraz własnych badań ankietowych przeprowadzonych w 2009r. i w 2015r. Pogłębiona analiza nowych pokryzysowych tendencji w zachowaniach konsumpcyjnych i wzorach konsumpcji współczesnych Polaków, odwołująca się do dostępnych danych statystycznych, raportów badawczych oraz wyników badań empirycznych może dostarczyć użytecznych wskazówek i rekomendacji dla decydentów kształtujących politykę gospodarczą, menedżerów i korporacyjnych strategów.

Słowa kluczowe: kryzys gospodarczy, zachowania konsumentów, Polska

\section{DOI: 10.7862/rz.2015.mmr.58}

Tekst złożono w redakcji: luty 2016

Przyjęto do druku: luty 2016 